\title{
«Cosas que hacen que valga la pena vivir»: de Marcial a Christophe Plantin
}

\section{Gabriel Laguna Mariscal}

\section{(2) OpenEdition}

1 Journals

Edición electrónica

URL: https://journals.openedition.org/cher/2684

DOI: $10.4000 /$ cher.2684

ISSN: 2803-5992

\section{Editor}

Presses universitaires de Strasbourg

\section{Edición impresa}

Fecha de publicación: 27 junio 2017

Paginación: 55-71

ISBN: 978-2-86820-961-0

ISSN: 1968-035X

\section{Referencia electrónica}

Gabriel Laguna Mariscal, ««Cosas que hacen que valga la pena vivir»: de Marcial a Christophe Plantin», reCHERches [En línea], 18 | 2017, Publicado el 01 diciembre 2021, consultado el 15 diciembre 2021. URL: http://journals.openedition.org/cher/2684 ; DOI: https://doi.org/10.4000/cher.2684

\section{(c) (i) (2)(2)}

Ce(tte) œuvre est mise à disposition selon les termes de la Licence Creative Commons Attribution Pas d'Utilisation Commerciale - Partage dans les Mêmes Conditions 4.0 International. 


\title{
"Cosas que hacen que valga la pena vivir»: de Marcial a Christophe Plantin
}

\author{
GabRIEL LAgUNA MARISCAL
}

\begin{abstract}
$\mathrm{E}^{1}$ epigrama X 47 de Marcial es uno de los poemas más famosos del poeta y ha tenido una recepción literaria muy rica en la tradición occidental, desde el Renacimiento hasta nuestros días ${ }^{2}$. He dedicado un trabajo anterior al análisis de la estructura, contenido y tema de este epigrama, así como a su recepción en la literatura española (Laguna Mariscal 2000a). En esta contribución me propongo repasar las características de forma literaria y de contenido filosófico que hicieron del epigrama un modelo de imitación y reelaboración. Posteriormente, se rastrearán los mecanismos de difusión del epigrama en la cultura europea, prestando especial consideración a la transmisión indirecta en antologías, florilegios y libros de erudición. Como consecuencia de esta popularidad se explican las numerosas evocaciones del poema. Entre estas destaca el soneto «Le bonheur de ce monde» del impresor francés Christophe Plantin. En este trabajo propondremos un análisis literario y cultural del poema de Plantino. Finalmente, y como corolario, recordaremos otras recreaciones del epigrama de Marcial elaboradas por autores modernos, incluso en el seno de géneros de la cultura popular como el Musical y el rap.
\end{abstract}

* Catedrático de Filología latina de la Universidad de Córdoba.

1 Este trabajo se inscribe en el Proyecto de Investigación FFI2009-13368, financiado por el MICIIN y titulado «Las Sátiras de Horacio: edición, comentario filológico y literario, y estudio de su recepción». Deseo agradecer al profesor José Luis Moralejo haber llamado mi atención sobre el soneto de Plantino.

2 Cf. Giulian (1930: 115); Cristóbal López (1987: 174); Sullivan (1991: 50 y 216-217); Ramírez de Verger - Fernández Valverde (1997: 59-63); Laguna Mariscal (2000a y 2003). 


\section{El hipotexto: Marcial X 47}

Marcial dirige su epigrama X 47 a su amigo y patrón Lucio Julio Marcial, mencionado en el verso 2 con el vocativo Iucundissime Martialis. El destinatario del poema, por tanto, es homónimo del autor en lo que se refiere a su cognomen. No se trata, pues, de que Marcial converse consigo mismo, como a veces se ha apuntado. He aquí el texto latino, acompañado de una traducción castellana:

Vitam quae faciant beatiorem,

Iucundissime Martialis, haec sunt:

Res non parta labore, sed relicta;

Non ingratus ager, focus perennis;

Lis numquam, toga rara, mens quieta

Vires ingenuae, salubre corpus;

Prudens simplicitas, pares amici;

Convictus facilis, sine arte mensa;

Nox non ebria, sed soluta curis;

Non tristis torus, et tamen pudicus;

Somnus, qui faciat breves tenebras:

Quod sis, esse velis nihilque malis;

Summum nec metuas diem nec optes.

Las condiciones que procuran una vida algo feliz, entrañable Marcial, son estas:

hacienda no conseguida afanosamente, sino heredada;

un campo agradecido, fuego constante;

ningún pleito, toga rara vez, espíritu tranquilo;

vigor natural, cuerpo sano;

juiciosa sencillez, amigos de igual condición;

alimento frugal, mesa sin lujo;

la noche no ebria, más carente de cuitas;

el lecho alegre, pero a un tiempo casto;

un sueño que acorte el tiempo oscuro;

querer ser lo que eres, y no preferir nada más;

no temer el postrero día, ni desearlo.

Es fácil enunciar el tema principal de epigrama como "Condiciones que procuran una vida feliz», prácticamente coincidente con la noción expresada en el verso inicial del poema: Vitam quae faciant beatiorem ${ }^{3}$. El poema no puede considerarse un epigrama en estricto sentido desde el punto de vista métrico, por la sencilla razón de que no está escrito en dísticos elegíacos, sino que consta de trece endecasílabos falecios. En cuanto a la forma literaria, el texto se estructura en dos partes:

3 El título mismo del epigrama fue imitado y reelaborado en la Tradición Clásica. Ya la primera imitación en España, obra de Cristóbal de Castillejo, se titula «Vida buena y descansada». El soneto de Plantino se tituló «Le bonheur de ce monde» y la composición de Juan de Jáuregui «De la felicidad de la vida». Todavía una película de Manuel Gómez Pereira del 2004 se titula Cosas que hacen que la vida valga la pena. 
I) Una sección inicial de planteamiento (vv. 1-2), que presenta explícitamente el tema.

II)Una segunda sección, más amplia y enjundiosa (vv. 3-13), que consiste en la enumeración pormenorizada de las principales condiciones y requisitos que, en opinión del autor, contribuyen a procurar la felicidad en la vida. Esta sección está dominada por dos rasgos formales o estilemas: la parataxis y la oración nominal.

\section{Contenido epicúreo del epigrama X 47 de Marcial}

Marcial pretendió exponer en este epigrama un ideario vital de raigambre epicúrea. Para ello, se sirvió de fuentes literarias griegas y latinas, entre las que destacan el propio Epicuro, así como Lucrecio (que compuso su poema didáctico De rerum natura con el objetivo de difundir la secta epicúrea en Roma) y Horacio. A continuación pasaré revista a los principales motivos de carácter epicúreo que desarrolla el poema, con indicación de sus principales fuentes.

\subsection{La vida feliz, objetivo de la filosofía}

Ya el propio enunciado que presenta el tema principal del epigrama es epicúreo: Vitam quae faciant beatiorem (v. 1: «Condiciones que procuran una vida algo feliz»). Para Epicuro la filosofía no era solo un saber teórico y objetivo, sino una actitud vital y práctica que proporciona felicidad a la vida ${ }^{4}$. En un fragmento que comenta esta actitud leemos: «y por eso decía Epicuro que la filosofía es una actividad que con palabras y razonamientos proporciona una vida feliz» (frag. 221 Usener).

En el corpus que nos ha transmitido Diógenes Laercio de Epicuro documentamos hasta en tres ocasiones la afirmación expresa, por parte de Epicuro, de que la meta de la filosofía es lograr que los hombres alcancen una

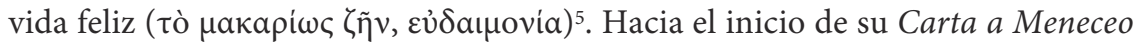
declara: «Debemos meditar, por tanto, sobre las cosas que nos reportan felicidad

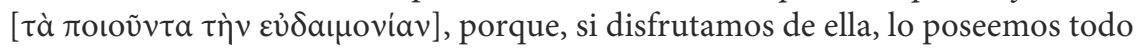
$y$, si nos falta, hacemos todo lo posible para obtenerla $\aleph^{6}$. Nótese, por un lado, cómo Epicuro introduce el postulado a modo de presentación inicial de la carta (esto es, como programa filosófico); de igual manera, y en homenaje a Epicuro, la frase constituye el arranque del epigrama.

4 Léase el capítulo «La finalidad del filosofar» en el libro que a Epicuro dedica García Gual (1981: 54-71), así como Lledó (1995: 63-70).

5 En Diógenes Laercio X 128, 4; X 128, 11; y X 134, 7. Sobre el alcanzar la vida feliz como meta de la filosofía (no necesariamente epicúrea), véanse igualmente Cicerón, Fines V 68, Séneca, Epistulae morales XLIV 7 y Boecio, Consolatio philosophiae III 2, 2. Recuérdese, además, que Séneca escribió un tratado con el explícito título de $D e$ vita beata.

6 Epicuro, en Diógenes Laercio X 122 (Usener 1976: 59). La traducción es de Jufresa (1994: 58), de quien proceden igualmente el resto de las traducciones de Epicuro aducidas en este trabajo. 


\subsection{Dicotomía cuerpo sano / mente tranquila}

En uno de los tres textos aludidos antes, en que Epicuro propone la felicidad vital como meta de la filosofía, el filósofo especifica que el contenido concreto de esa felicidad es el placer: «afirmamos que el placer es el principio y fin de una vida feliz» (Diógenes Laercio X 128, 11). El placer, a su vez, se logra mediante la satisfacción o rechazo de los deseos, con vistas siempre a una meta dicotómica: la salud del cuerpo y la tranquilidad del espíritu: «De modo que, si los conocemos bien [sc. los deseos] sabremos relacionar cada elección o cada negativa con la salud del cuerpo o la tranquilidad del alma, ya que este es el objetivo de una vida feliz» ${ }^{7}$. Esa dicotomía salud del cuerpo / tranquilidad del espíritu fue también expuesta claramente por Lucrecio (II 16b-19). Con esos precedentes filosóficos no debe sorprender que Marcial dedique también una frase al cuerpo sano (6 salubre corpus) y otra al espíritu tranquilo (5 mens quieta).

\subsection{La tranquilidad del espíritu y el sueño tranquilo}

Esa noción de la tranquilidad del espíritu, o imperturbabilidad, que en griego se expresa mediante el término ả $\alpha \alpha \rho \xi \xi$ í, ocupa una posición central en el ideario epicúreo. La ataraxía consiste, a su vez, en la ausencia de preocupaciones y de miedos. Lucrecio, en concreto, vierte el concepto griego en latín mediante diferentes giros fraseológicos, como mentem [...] cura semota metuque (II 18-19), vacuum pectus... curaque solutum (II 46), animi pacem (III 24) o securam quietem (III 939) ${ }^{8}$. Es evidente que Marcial está aludiendo a ese ideal epicúreo y lucreciano en los sintagmas mens quieta (5) y nox... soluta curis (9).

Un corolario de esa tranquilidad anímica es el sueño tranquilo del individuo humilde ${ }^{9}$, algo que Marcial destaca (11), y que ya Epicuro había considerado un bien, en contraste con el insomnio de los ricos: «Es mejor para ti yacer tranquilo sobre un lecho de hojarasca que agitarse inquieto poseyendo un lecho de oro y una suntuosa mesa» (frag. 207 Usener).

\subsection{Afanes que perturban el sosiego del espíritu}

Epicuro (y, en su senda, Lucrecio) rechazaba cualquier actividad que pudiera interferir con la deseable tranquilidad anímica: denostaba la participación política en la vida pública ${ }^{10}$, la dedicación a los negocios, la superstición religiosa (esto es, el miedo a los dioses), el miedo a la muerte, y hasta el matrimonio y

7 Diógenes Laercio X 128, 4.

8 Parece que la noción la introdujo Cicerón en latín, con el término quies (Tusc. I4). Horacio prefirió sollicitae iucunda oblivia vitae (serm. II 6, 62); Séneca habló de inturbata publicis occupationibus quies (epist. LXXIII 10). Léase Laguna Mariscal (1996: 248 y n. 4).

9 El tópico tiene gran tradición literaria: Virgilio, georg. II 470-71; Horacio, epod. II 28; carm. II 16, 15; III 1, 21-23; epist. I 10, 18; Séneca, epist. XC 41; Marcial I 49, 35-36; II 90, 10; XII 57, 24-25; Estacio, silu. III 5, 86. Léase Nisbet/Hubbard (1978: 261) y Laguna Mariscal (1992: 383).

10 Diógenes Laercio X 10 y 119; frag. 552 Usener. Léase García Gual (1981: 62-67). 
la procreación de hijos. Marcial, en idéntica línea, denuesta la dedicación a los negocios para conseguir riqueza (v. 3), así como los pleitos (5 Lis numquam) y la política (5 toga rara).

\subsection{La amistad como bien epicúreo}

Es muy significativa también la mención concreta que Marcial hace de la amistad como de un bien: pares amici (7). Pues es sabido que Epicuro tenía en alto grado a la amistad ${ }^{11}$, según nos testimonia Cicerón: Epicurus... dicit... nihil maius esse amicitia, "Epicuro afirma que no existe nada más importante que la amistad» (Fin. I 65). El propio Epicuro había establecido taxativamente: «De cuantos bienes proporciona la sabiduría para la felicidad de toda una vida, el más importante es la amistad» (Máximas Capitales 27). Teniendo en cuenta este background filosófico del tema de la amistad, cobra particular sentido la mención de Marcial.

\subsection{La autarquía y la dieta frugal}

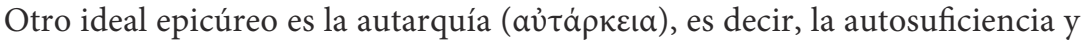
conformidad con lo mucho o poco que se posea. Cedamos de nuevo la palabra a Epicuro:

La autarquía la tenemos por un gran bien, no porque debamos siempre conformarnos con poco, sino para que, si no tenemos mucho, con este poco nos baste, ${ }^{12}$

y Marcial afirma que lo ideal para lograr la felicidad es no pretender más de lo que se es: Quod sis, esse velis nihilque malis $(12)^{13}$. La idea tiene precedentes en Horacio y el propio Marcial la había desarrollado en otro lugar ${ }^{14}$.

Como corolario particular de ese ideal de autarquía, el epicureísmo propugna una vida sencilla y frugal. Epicuro afirma que «todo lo que la Naturaleza reclama

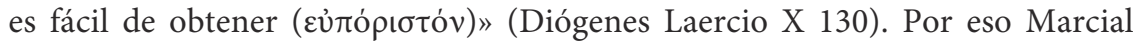
rechaza el lujo en la mesa ( 8 sine arte mensa) y defiende la "comida al alcance de la mano» (8 convictus facilis); todo ello, impregnado de una «sensata sencillez» (7 prudens simplicitas).

\subsection{Ni temer ni desear la muerte}

El último postulado de Marcial, como culminación solemne de la enumeración, es la invitación a no temer ni desear la muerte (v. 13). También

11 Léase el capítulo «La amistad», en García Gual (1981: 210-217), así como Lledó (1995: 115-126).

12 Diógenes Laercio X 130. Léase García Gual (1981: 67-71). Sobre la virtud de vivir felizmente con poco, como tópico literario, $c f$. Horacio, carm. II 16, 13-16; serm. II 2, 1; Tibulo I 1, 25; Séneca, Med. 333.

13 Resulta harto significativo que, como enseguida veremos, el epigrama X 47 de Marcial

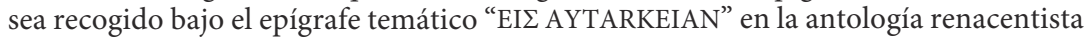
Epigrammata selecta de J. Soter (1528).

14 Horacio, serm. I 2, 46; II 6, 4; carm. II 18, 11-14; Marcial IV 77, 1-2. 
documentamos un precedente claro de este ideal en Epicuro, para quien el cultivo de la filosofía debe mostrar que la muerte no es un mal y que, por tanto, el sabio no debe ni temerla ni desearla:

El peor de los males, la muerte, no significa nada para nosotros, porque mientras vivimos no existe, y cuando está presente nosotros no existimos. [...] A pesar de ello, la mayoría de la gente unas veces rehúye la muerte viéndola como el mayor de los males, y otras la invoca para remedio de las desgracias de esta vida. El sabio, por su parte, ni desea la vida ni rehúye el dejarla, porque para él el vivir no es un mal, ni considera que lo sea la muerte. (Diógenes Laercio X 126)

Séneca nos confirma que ésa era la actitud de Epicuro: obiurgat Epicurus non minus eos qui mortem concupissent quam eos qui timent, «Epicuro recrimina no menos a los que desean la muerte que a los que la temen»(Séneca, Epist. XXIV 22).

\subsection{Epicureísmo del epigrama}

Con lo expuesto, parece claro que Marcial se propuso exponer en este epigrama un ramillete de postulados de la filosofía epicúrea, si bien bajo un ropaje poético. Esto es, Marcial hace una versión poética y sintética de lo que sería un tratado de doctrina epicúrea. Por ello, prácticamente todos los puntos del ideario vital de Marcial pueden documentarse, y a veces al pie de la letra, en Epicuro o en sus seguidores latinos.

\section{Recepción literaria de Marcial X 47}

Como ya han apuntado y estudiado varios autores, este epigrama de Marcial es uno de los que más predicamento tuvieron en Europa, conociendo numerosas traducciones, imitaciones y recreaciones. Es fácil atisbar la razón. Se trata de un poema de aparente sencillez y de estructuración nítida (Sullivan 1991: 216). Conceptualmente muestra un ideario epicúreo, y sin embargo ese epicureísmo es bastante compatible con el neoestoicismo cristiano de numerosos escritores europeos del Renacimiento. Además, la estructura del epigrama permitía inspirar variaciones personales, que, respetando la organización general, diferían en los detalles con el objetivo de adecuarse a los gustos e ideología del autor imitador. Asimismo, el epigrama de Marcial presenta ya in nuce el ideal de la vida retirada en el campo (v. 4) y del menosprecio de la corte ( 5 toga rara). Todos estos datos, tomados conjuntamente, propiciaron su éxito.

A la hora de estudiar la recepción de un texto clásico, es imprescindible rastrear su transmisión, tanto directa como indirecta. Como medio directo de difusión del texto de Marcial hay que recordar, en primer lugar, que la edición príncipe de los epigramas de Marcial apareció tempranamente, en 1470 o 1471; y que antes de 1600 se habían impreso más de cuarenta ediciones en toda Europa, lo que vendría a demostrar su popularidad (Sullivan 1991: 264-270).

Además, Claudio Guillén nos recuerda la necesidad de investigar los intermediarios culturales (Guillén 2005: 75-77). Conviene precisar que muchos autores recurrían para su inspiración a la lectura no de los textos originales, sino 
de las selecciones recogidas por transmisión indirecta en antologías, florilegios y libros de erudición ${ }^{15}$. Bastantes de estos libros recogen epigramas de Marcial. Y es que Marcial ofrecía un variopinto muestrario de testimonios sobre numerosos aspectos de la vida romana, por lo que proporcionaba un material idóneo que incorporar a este tipo de recopilaciones (Ramírez de Verger/Fernández Valverde 1997: 43).

Para citar ejemplos relevantes, este epigrama X 47 de Marcial es aducido literalmente en la antología bilingüe (griego-latín) de epigramas Epigrammata graeca veterum elegantissima de J.Soter (1528), bajo el epígrafe temático

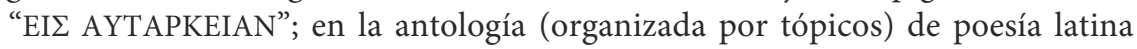
Illustrium poetarum flores (1538) de Octaviano Mirándula, dentro del tópico «De vita» y bajo el epígrafe explicativo «Quae vitam beatiorem efficiant» (que, como se ve, no es más que una leve paráfrasis del primer verso de Marcial); en la también antología, más amplia, de Joseph Lang Florilegii magni seu Polyantheae floribus novissimis sparsae (1607); y en el «Discurso XLIII» del ensayo erudito Agudeza y arte de ingenio (1648) de Baltasar Gracián ${ }^{16}$.

Como consecuencia de esta amplia difusión del epigrama X 47 en ediciones, antologías y libros de erudición, se documentan media docena de imitaciones o traducciones libres en la literatura española de los siglos XVI y XVII. El primer autor de estas traducciones fue Cristóbal de Castillejo: este poeta alcanzó fama de ser medievalizante y hostil a la poética del Renacimiento, pero lo cierto es que escribió su composición «Vida buena y descansada» en imitación de un texto clásico como el epigrama X 47 de Marcial. Eso sí, su composición está escrita en una forma métrica castiza, el romance en octosílabos. Joaquín Romero de Cepeda publicó en 1582 su versión del poema «Lo que a la vida haze mas contenta», escrita en 28 endecasílabos blancos. También el anónimo autor (seguramente el capitán Andrés Fernández de Andrade) de la «Epístola moral a Fabio», escrita en tercetos encadenados antes del 1613, imita en los versos 127-132 algunos pasajes de Marcial. Juan de Jáuregui dedicó la segunda parte (vv. 28-61) de su extenso poema «De la felicidad de la vida. Imitación de Pentadio y Marcial en sus epigramas» a imitar con amplificación el poema de Marcial; también está escrito en tercetos encadenados ${ }^{17}$. Baltasar Gracián incluyó en su Agudeza y arte de ingenio (1648) el texto de Marcial, acompañado de una traducción castellana de Manuel Salinas.

15 Sobre la importancia de estos florilegios como fuentes de inspiración, véanse las discusiones de Martindale (1990: 15); Moss (1996); Laguna Mariscal (2000b: 427-428 y n. 25); y Traver Vera (2014).

16 De las obras citadas se hicieron varias ediciones. Cito por las ediciones usadas: Soter (1528: 19); Mirándula (1553: 716); Lang (1639: col. 3132); Baltasar Gracián en Correa Calderón (1969: II 124).

17 Las evocaciones de Marcial X 47 en Juan de Jáuregui y en la «Epístola Moral a Fabio» fueron señaladas por Cristóbal López (1987: 174). 
Documentamos una interesante traducción (interpretatio) del epigrama de Marcial, bastante condensada y literal, en un soneto atribuido tanto a Francisco López de Zárate como a Lope de Vega (1562-1635). Esta versión convierte los trece endecasílabos falecios del original en los catorce endecasílabos de un soneto, de modo que es prácticamente equivalente en extensión. Ha de recordarse en este punto que los literatos del Renacimiento, tanto en la preceptiva teórica como en la práctica poética, juzgaban que el soneto era el equivalente vernáculo del epigrama grecolatino ${ }^{18}$. He aquí el texto del soneto de López de Zarate / Lope de Vega ${ }^{19}$ :

Estas las cosas son que hacen la vida

Agradable, Marcial, más fortunada,

Hacienda por herencia, no ganada

Con afán, heredad agradecida.

Hogar continuo, nunca conocida

Querella o pleyto, toga poco usada,

Fuerzas, salud, el alma sossegada,

Sencillez cuerda, amigos a medida.

Mesa sin artificio, leve pasto,

Noche sin embriaguez, ni cuidadosa,

Lecho no solitario, pero casto.

Sueño que abrevie la tiniebla fea;

Lo que eres quieras ser, y no otra cosa,

Ni morir teme, ni vivir desea.

Como se aprecia, el poeta ha conseguido una gran fidelidad y una gran condensación poética. Los ripios de relleno son muy escasos (2 "Agradable», 6 «o pleito», 12 «fea»). Globalmente, puede calificarse de una versión muy lograda, que además ha salido airosa con las imposiciones métricas del soneto.

\section{4. «Le bonheur de ce monde» de Christophe Plantin}

Una vez que hemos establecido las cualidades del epigrama de Marcial que explican su pervivencia, los medios de difusión directa e indirecta del texto durante el Renacimiento y las principales estrategias de traducción y

18 Ya, al menos, desde el tratado de Lorenzo de Medici Commento sopra alcuni de suoi sonetti, de 1476. Igual equivalencia entre soneto vernáculo y epigrama grecolatino postulan Fernando de Herrera en sus Anotaciones a la poesía de Garcilaso (1580), así como Díaz Rengifo (1592) y Baltasar Gracián (1648). Para todo ello, léase Cristóbal López (1987: 152).

19 Noticia y texto en Giulian (1930: 58), con atribución a López de Zarate. El soneto es incluido en López de Zárate (1651: 82) y mencionado en Jauralde Pou (2012, s.v. "López de Zárate, Francisco"). En cambio, parece que la primera atribución a Lope de Vega data de 1776 (Vega Carpio 1776: 441), y es citada aparentemente con aprobación por Ménendez Pelayo (1952-1953: IV 234). No se encuentra el soneto de Lope en las ediciones modernas de su poesía, como la de Blecua (1983). 
recreación que se la han aplicado, nos situamos en una plataforma idónea para contextualizar y comprender la recreación de Plantino.

El famoso impresor renacentista Cristóbal Plantino (Christophe Plantin) (1520-1589), de patria francesa, estableció una imprenta en Amberes en 1550. A su muerte, su yerno Mureto siguió con el negocio. La imprenta continuó en el mismo local ininterrumpidamente desde 1576 hasta 1876, fecha en que el último propietario de la casa Plantino-Mureto vendió el edificio al concejo de Amberes, con toda su colección de manuscritos, libros impresos, grabados y obras de arte. Hoy el centro es un Museo de la Imprenta, el Museo Plantin-Muretus, donde los visitantes y turistas pueden comprar un póster u octavilla que consiste en la reproducción de un soneto de Christophe Plantin titulado «Le bonheur de ce monde» («La felicidad de este mundo»), impreso con la tipografía del famoso impresor. Parece que el soneto fue impreso por vez primera hacia 1579, sin mención de autoría, aunque tradicionalmente se ha considerado obra del propio Plantino.

Presento a continuación el texto, acompañado por una traducción propia al castellano:

LE BONHEUR DE CE MONDE

SONNET

Avoir une maison commode, propre et belle,

Un jardin tapissé d'espaliers odorans,

Des fruits, d'excellent vin, peu de train, peu d'enfans,

Posseder seul sans bruit une femme fidèle,

N'avoir dettes, amour, ni procès, ni querelle,

$\mathrm{Ni}$ de partage à faire avecque ses parens,

Se contenter de peu, n'espérer rien des Grands,

Régler tous ses desseins sur un juste modèle,

Vivre avecque franchise et sans ambition,

S'adonner sans scrupule à la dévotion,

Dompter ses passions, les rendre obéissantes,

Conserver l'esprit libre, et le jugement fort,

Dire son Chapelet en cultivant ses entes,

C'est attendre chez soi bien doucement la mort.

\section{LA FELICIDAD DE ESTE MUNDO \\ SONETO}

Tener una casa cómoda, limpia y hermosa, un jardín tapizado de fragantes enredaderas, frutas, buen vino, poca servidumbre, pocos hijos, poseer solo, sin algazara, una fiel esposa.

No tener deudas, amor, pleito ni demanda,

ni reparto que hacer con los parientes, contentarse con poco, no esperar nada de los Grandes, acompasar los propios designios sobre un justo modelo. 
Vivir con desahogo y sin ambición, entregarse sin beatería a la devoción,

domar las pasiones, hacerlas obedientes.

Conservar el espíritu libre y el juicio firme,

rezar el rosario cultivando los injertos,

es esperar, seguro de sí, muy dulcemente la muerte.

Salta a la vista que el soneto de Plantino es una recreación literaria del epigrama X 47 de Marcial. Como primera aproximación, puede advertirse que el epigrama latino se vierte bajo la forma métrica de un soneto vernáculo, de acuerdo con la tendencia habitual en el Renacimiento, examinada arriba. La presentación del tema del soneto está en el paratexto que le sirve de título, de modo que el título recrea los dos primeros versos del epigrama de Marcial. La estructura del soneto quedaría, pues, como sigue:

I) Presentación del tema (título).

II)Enumeración de requisitos para la felicidad (vv. 1-14).

En la forma destaca la enumeración de requisitos mediante la parataxis y el uso de infinitivos. Respecto al contenido (requisitos para la felicidad), Plantino expone unos requisitos propios de una ética moderada, cristiana y burguesa, no muy ajena ni al epicureísmo moderado y ecléctico de Marcial ni al neoestoicismo renacentista. Algunos puntos de coincidencia con Marcial serían la alusión a la esposa y a la felicidad conyugal (v. 4), el gusto por la vida rural y alejada de la ciudad $(2-3,13)$, la vida y dieta frugales $(3,7)$, el rechazo de la litigación (5) y la alusión final a la espera sosegada de la muerte (14). Algunas ideas propias de Plantino son la preferencia por una religiosidad moderada $(10,13)$ y la aversión a tener muchos hijos (3). Incluso en estos dos puntos Plantino sigue la tradición epicúrea, ya que el epicureísmo combatió la religiosidad fanática y disuadía de la procreación de hijos ${ }^{20}$.

\section{Versiones (post)modernas del epigrama}

El epigrama de Marcial ofrecía posibilidades claras como modelo para la expresión de un ideario ético, aunque este ideario difiriera en sus detalles de las preferencias del epigramatista latino. Además, algunos principios de Marcial, como la búsqueda de sosiego mental o la huida a la naturaleza, sintonizan a las mil maravillas con algunas tendencias modernas y postmodernas como el movimiento hippy, el ecologismo, los movimientos antisistema o los indignados.

20 Sobre el denuesto epicúreo de la religiosidad, cf. Lucrecio I 62-101, V 154-194, con el estudio de Martínez Lorca (1996), así como Horacio, Serm. I 7, 97-104 y Carm. I 34, 1. Sobre el rechazo de la procreación de hijos pueden compararse Terencio, Ad. 867-868 y Propercio II 7, 13-14, con comentario de Laguna Mariscal (1994: 268-269 y n. 21). Para la cuestión en Epicuro, léanse Chilton (1960) y Brenan (1996). Por su parte, Baertschi (1996) ha estudiado la tradición filosófica y sociológica del ideal «Avoir peu d' enfants», aunque sin abordar la posición de la escuela epicúrea. 


\subsection{Jaime Gil de Biedma}

En la poesía contemporánea del siglo xx, Jaime Gil de Biedma (1929-1990) compuso el poemita "DE VITA BEATA», incluido en el libro Poemas póstumos (1968). El título en latín recuerda a Marcial, pero en realidad es la evocación exacta del título de un ensayo de Séneca:

DE VITA BEATA

En un viejo país ineficiente, algo así como España entre dos guerras civiles, en un pueblo junto al mar, poseer una casa y poca hacienda y memoria ninguna. No leer,

no sufrir, no escribir, no pagar cuentas,

$\mathrm{y}$ vivir como un noble arruinado

entre las ruinas de mi inteligencia.

Este texto expone en qué consiste la felicidad. La primera parte que distinguíamos en el tópico (la presentación del tema) se encuentra en el título (algo similar hemos visto en el soneto de Plantino). A continuación el poeta explicita las condiciones de dicha felicidad, en forma de enumeración paratáctica de requisitos, con tendencia a la frase nominal. Todo ello acusa el modelo de Marcial. Ciertamente las coincidencias de detalle con Marcial son mínimas y quizá casuales («hacienda» = res, "No sufrir» Nox... soluta curis). De hecho, parece muy probable que el modelo inmediato de Gil de Biedma fuera precisamente el soneto citado de Plantino. Algunas coincidencias significativas sugieren la posible imitación: "Avoir une maison commode» = "poseer una casa», «Se contenter de peu» = «poseer... poca hacienda», «N'avoir dettes» = «no pagar cuentas». En conclusión, Gil de Biedma ha imitado tanto el tema general como la forma poética del texto de Marcial, pero no los pormenores del contenido, para los cuales ha usado probablemente el texto de Plantino como modelo inmediato.

\subsection{My Favourite Things}

La canción «My favourite things» ${ }^{21}$ fue compuesta por Rodgers y Hammerstein como uno de los números del musical de Broadway The sound of music, estrenado en 1959. En 1965 se produjo una película homónima, dirigida por Robert Wise, en la que Julie Andrews cantaba la canción en el papel de María. Desde entonces se ha convertido en todo un clásico, del que se han hecho numerosas versiones (entre las que destaca la versión jazz de John Coltrane).

La canción enumera los pequeños placeres de la vida que contribuyen a dar la felicidad al sujeto lírico. La estructura es sencilla: en cada una de las tres estrofas encontramos una enumeración de cosas placenteras y luego la

21 Puede recabarse la información sobre la canción en la entrada «My Favourite Things (song)» de la Wikipedia en inglés: http://en.wikipedia.org/wiki/My_Favorite_ Things_\%28song\%29. 
recopilación «These are a few of my favourite things». Las estrofas van seguidas de un estribillo en que se explica que este conjunto de cosas favoritas alivia al sujeto lírico de las penas de la vida y de los momentos difíciles. He aquí la letra:

Raindrops on roses and whiskers on kittens,

Bright copper kettles and warm woolen mittens,

Brown paper packages tied up with strings:

These are a few of my favorite things.

Cream colored ponies and crisp apple strudels,

Doorbells and sleigh bells and schnitzel with noodles,

Wild geese that fly with the moon on their wings:

These are a few of my favorite things.

Girls in white dresses with blue satin sashes,

Snowflakes that stay on my nose and eyelashes,

Silver white winters that melt into springs:

These are a few of my favorite things.

When the dog bites,

When the bee stings,

When I'm feeling sad,

I simply remember my favorite things

And then I don't feel so bad.

\subsection{Luis Alberto de Cuenca}

El poeta contemporáneo y filólogo clásico Luis Alberto de Cuenca (Madrid 1950), perteneciente a la generación de los 70 o «Novísimos», compuso el siguiente poema ${ }^{22}$, incluido en su libro Por fuertes y fronteras (1996: 65):

SOBRE UNA CARTA DE JOHN KEATS

Un dios por quien jurar. El buen tiempo (supongo).

La salud. Muchos libros. Un paisaje de Friedrich.

La mente en paz. Tu cuerpo desnudo en la terraza.

Un macizo de lilas donde rezar a Flora.

Dos o tres enemigos y dos o tres amigos.

Todo eso junto es la felicidad.

También hay aquí plena coincidencia con Marcial en el tema general del tópico: la definición de la felicidad. Respecto a la estructura, Luis Alberto de Cuenca conserva las dos partes que distinguíamos en el epigrama de Marcial, aunque alterando el orden: en la sección inicial (vv. 1-5) enumera los requisitos para una vida feliz, con estilo paratáctico y dominio de la frase nominal (no hay un solo verbo en forma personal en esta sección); y en la segunda parte, constituida por el último verso (6 «Todo eso junto es la felicidad»), recapitula. Con respecto al detalle de los requisitos, de Cuenca recoge algunos elementos de Marcial, a veces literalmente: «La salud»= salubre corpus, «La mente en

22 Para la influencia clásica en la poesía de Luis Alberto de Cuenca puede consultarse Martínez Sariego/Laguna Mariscal (2010). 
paz» = mens quieta, "y dos o tres amigos» pares amici. Otros de sus requisitos nos recuerdan a Marcial más lejanamente: "Tu cuerpo desnudo en la terraza" introduce un contenido de sensualidad que evoca Non tristis torus de Marcial; «Dos o tres enemigos» recuerda y corrige el Lis numquam del epigramatista latino (estaríamos, en este último caso, ante una imitatio cum variatione); por último, el verso «Un paisaje de Friedrich» es reminiscente del ager de Marcial. Lo curioso es que Luis Alberto de Cuenca no imita exclusivamente a Marcial sino, en virtud del procedimiento imitativo que llamamos contaminatio o «imitación compuesta» (Lázaro Carreter 1979: 94-97), parece incorporar simultáneamente detalles del poema de Jaime Gil de Biedma: así, su aserto «Muchos libros» está corrigiendo la preferencia «No leer» de Biedma.

\subsection{Rap en un contexto educativo}

En el IES Vegas Bajas de Montijo (Badajoz) un conjunto de profesores llevaron a cabo una experiencia didáctica interdisciplinar, titulada Musa Renascens, consistente en el estudio y recreación de una serie de tópicos literarios clásicos ${ }^{23}$. Uno de los tópicos abordados fue el de los requisitos para una vida feliz (De vita beata), tomando como modelo precisamente el epigrama X 47 de Marcial.

Se solicitó a los alumnos que compusieran recreaciones literarias del tópico ${ }^{24}$. Un grupo de ellos compusieron un rap titulado «Consejos para una vida feliz» ${ }^{25}$, cuya letra es una recreación del epigrama de Marcial, conservando el tema principal y la estructura, pero adaptando los contenidos a los gustos e intereses de los jóvenes autores. He aquí el estribillo y la primera estrofa de la letra del rap, obra de Roberto Cacho y José Flecha:

Son consejos para una vida feliz,

consejos, van dirigidos a ti.

Consejos, para una vida feliz.

Consejos, yo los suelto están ahí.

Los ingredientes que hacen la vida más feliz:

una buena ensaladilla rusa... que no le falte el maíz.

Tener la cabeza amueblada, con algún que otro matiz.

Currar poco, ganar mucho y algo importante que no "farte":

tener un buen techo donde cobijarte.

Si hace frío o hace calor, algo importante yo quiero: 10

en verano una piscina y en invierno un buen brasero.

No te rompas mucho el lomo cuando cojas aceitunas;

23 La dirección URL del portal Musa Renascens es http://serbal.pntic.mec.es/atrv0002/ musa_renascens/index.html. Un informe sobre la experiencia y el portal puede encontrarse en Feijoo Lorenzo, Vázquez Hernández, Traver Vera (2012-2013).

24 Una selección de recreaciones puede verse aquí: http://serbal.pntic.mec.es/atrv0002/ musa_renascens/de_vita_al.html

25 Puede consultarse la letra completa y el video con la interpretación aquí: http://serbal. pntic.mec.es/atrv0002/musa_renascens/de_vita2.html 
ahorra un par de durillos, cómprate un "renault laguna".

Los lios con la justicia mejor mirarlos de lejos,

no te metan en la cárcel por robar un pestorejo.

Con un poquito de suerte, acabar bien los estudios,

para irnos luego a la playa cuando llegue el mes de julio.

Algo importante en la vida es tener buenos colegas,

como estos que hemos hecho en el "insti" Bajas Vegas.

\section{Conclusiones}

$\mathrm{Al}$ estudiar las características de fondo y forma literaria del epigrama X 47 de Marcial hemos apuntado que este texto estableció el modelo de un tópico literario ("Cosas que hacen la vida feliz») y hemos anticipado las posibles razones de su éxito posterior. el epigrama tuvo una rica transmisión durante el Renacimiento en antologías, florilegios y libros de erudición. Por otro lado, el poema se articula en una estructura nítida, fácil de imitar, y expone un ideario de epicureísmo moderado que sintonizaba a las mil maravillas con el neoestoicismo cristiano que primó en Europa en los siglos XVI y XVII. Además, el tópico literario tenía suficiente flexibilidad para que cada autor lo adaptara a sus gustos e intereses.

Todas estas condiciones explican el éxito del tópico y del epigrama. Desde el Renacimiento hasta nuestros días se compusieron numerosas traducciones y recreaciones. Solo en las letras hispanas documentamos media docena de imitaciones en los Siglos de Oro, que tradujeron, más o menos libre y parafrásticamente, tanto el contenido como la forma literaria.

El impresor francés Christophe Plantin, afincando en Amberes, escribió un soneto famoso, titulado «Le bonheur de ce monde», que es una recreación interesante del epigrama de Marcial. Ahora bien, los requisitos que propone para la consecución de la felicidad se mueven en una línea de filosofía neoestoica, burguesa, moderada y cristiana. En el fondo, esta versión ejemplifica la flexibilidad del tópico.

Finalmente, el tópico también ha tenido desarrollo en la poesía moderna y postmoderna, tanto en géneros de la cultura elevada como de la cultura popular. Dentro de la cultura elevada, hemos examinado poemas de Jaime Gil de Biedma y de Luis Alberto de Cuenca. En el seno de la cultura popular hemos rastreado la recreación del tópico en la canción «My Favourite Things» del musical The Sound of Music, así como en un rap compuesto por estudiantes en un contexto educativo. El acercamiento de los poetas y juglares contemporáneos al epigrama de Marcial es radicalmente distinto al de los poetas auriseculares: los poetas contemporáneos adoptan la forma literaria del epigrama (el «diseño retórico» de Lázaro 1979: 100-1) como cauce para expresar un contenido sustancialmente distinto. Pero siguen atestiguando la vitalidad de la poesía latina y de su vehículo lingüístico, el latín: no está muerta una lengua que transmite literatura viva y plenamente vigente. 


\section{Bibliografía}

Alberto de Cuenca L., 1996, Por fuertes y fronteras, Madrid, Visor.

Baertschi B., 1996, "Le bonheur, c'est... d'avoir "peu d'enfans"”, Folia Bioethica, 18 , p. $1-43$.

Blecua J. M., 1983, Lope de Vega. Obras poéticas, Barcelona, Planeta.

Boyancé P., 1969, Épicure, Paris, P.U.F.

Brenan T., 1996, «Epicurus on Sex, Marriage, and Children», Classical Philology, 91.4, p. 346-352.

Chilton C.W., 1960, «Did Epicurus approve of Marriage? A study of Diogenes Laertius X, 119», Phronesis, 5, p. 71-74.

Correa Calderón E., 1969, Baltasar Gracián. Agudeza y arte de ingenio, 2 vols., Madrid, Castalia.

Cristóbal López V., 1987, "Marcial en la literatura española», in: Actas del Simposio sobre Marco Valerio Marcial, poeta de Bílbilis y Roma, Ponencias, Zaragoza, U.N.E.D., p. 145-210.

Curtius E.R., 1955, Literatura europea y Edad Media latina, 2 vols., MéxicoMadrid, Fondo de Cultura Económica.

Feijoo Lorenzo F.J., Vázquez Hernández Á., Traver Vera Á.J., 2012-2013, «Musa Renascens: un proyecto de creatividad y dinamización educativa en bachillerato nocturno/Musa Renascens: a project of creativity and educational revitalization in night secondary school», Revista Electrónica de Investigación, Docencia y Creatividad, 2, p. 46-60. https://docs.google.com/ file/d/0B5Sju9aeFZ8AX1VGRm82ekIyYU0/edit

García Gual C., 1981, Epicuro, Madrid, Alianza Editorial.

Giulian A., 1930, Martial and the epigram in Spain in the sixteenth and seventeenth centuries, Philadelphia, University of Pennsylvania.

Greene T.G., 1982, The light in Troy. Imitation and discovery in Renaissance poetry, New Haven-London, Yale University Press.

Guillén C., 2005, Entre lo uno y lo diverso. Introducción a la Literatura Comparada (Ayer y hoy), Barcelona, Tusquets.

Hutton J., 1946, The Greek Anthology in France, Ithaca, Cornell University Press. Jufresa M., 1994², Epicuro. Obras, Madrid, Tecnos.

Jauralde Pou P., 2012, Diccionario Filológico de Literatura Española. Siglo XVII, 2 vols., Madrid, Castalia.

Laguna Mariscal G., 1992, Estacio, Silvas III, Madrid-Sevilla, Fundación Pastor de Estudios Clásicos-Universidad de Sevilla.

Laguna Mariscal G., 1994, «Invitación al matrimonio: en torno a un pasaje estaciano (silu. I 2, 161-200)», Emerita, 62, p. 263-288.

Laguna Mariscal G., 1996, «Philosophical topics in Statius' Silvae: sources and aims», in: Delarue F. (ed.), Epicedion. Hommage à P. Papinius Statius. 96-1996, Poitiers, La Licorne, p. 247-259. 
Laguna Mariscal G., 1998, «La poesía epigramática griega en su relación con la literatura romana: el tema amoroso», in: Brioso M., González Ponce F. J. (eds.), Actitudes literarias en la Grecia romana, Zaragoza, Pórtico, p. 93-121. Laguna Mariscal G., 1999, «En tierra, en humo, en polvo, en sombra, en nada: historia de un tópico literario», Anuario de Estudios Filológicos, 22, p. 199-213. Laguna Mariscal G., 2000a, "Cosas que procuran una vida feliz»: contenido y fortuna literaria del epigrama X 47 de Marcial», in: Homenaje a la Profesora Carmen Pérez Romero, Cáceres, Universidad de Extremadura, p. 321-337.

Laguna Mariscal G., 2000b, «La recepción de la poesía latina en la cultura humanística del Renacimiento: factores culturales y procedimientos imitativos», in: Marqués de la Encomienda et al., El humanismo extremeño. Estudios presentados a las 4as. Jornadas organizadas por la Real Academia de Extremadura en Trujillo en el 2000, Trujillo, Real Academia de Extremadura de las Letras y las Artes, p. 423-433.

Laguna Mariscal G., 2003, «Para vivir no quiero islas, palacios, torres: el tópico literario de la recusatio», Tradición Clásica, Septiembre 2003. http://www.uco. es/ callamag/Septiembre2003.htm

Lang J., 1639, Florilegii Magni seu Polyantheae Floribus Novissimis Sparsae, Libri Xx [...] studio dehinc \& operae Iosephi Langii meliore ordine dispositum, Coloniae, Ex Typographia Iacobi Stoer [Biblioteca Pública de Cáceres A/9.040].

Lazaro Carreter F., 1979, «Imitación compuesta y diseño retórico en la Oda a Juan de Grial», Anuario de Estudios Filológicos, 2, p. 89-119.

Lledó E., 1995, El epicureísmo, Madrid, Taurus.

López de Zarate F., 1651, Obras varias de Francisco López de Zarate. Dedicadas a diferentes personas, Alcalá, María Fernández.

Martindale C. \& M., 1990, Shakespeare and the uses of Antiquity, London-New York, Routledge.

Martínez Lorca A., 1996, «Lucrecio: una crítica ilustrada a la religión popular», in: Giannantoni G. y Gigante M. (eds.), Epicureismo Greco e Romano. Atti del Congreso Internazionale. Napoli, 19-26 maggio 1993, Napoli, Bibliopolis, p. 851-864.

Martínez Sariego M.M. y Laguna Mariscal G., 2010, «La mitología clásica en la poesía de Luis Alberto de Cuenca (1971-1996)», Cuadernos de Filología Clásica. Estudios Latinos, 30, p. 381-413.

Matas Caballero J., 1993, Juan de Jáuregui. Poesía, Madrid, Cátedra.

Menéndez Pelayo M., 1952-1953, Biblioteca de traductores españoles, 4 vols., Santander, Consejo Superior de Investigaciones Científicas.

Mirándula O., 1553, Illustrium Poetarum Flores, per Octavianum Mirandullam collecti, \& in locos communes digesti, Lugduni, Apud Ioan. Tornaesium et Guil. Gazeium [Ejemplar propiedad del autor]. 
Moss A., 1996, Printed commonplace-Books and the structuring of Renaissance though, Oxford, Clarendon Press.

Nisbet R. G. M. y Hubbard M., 1978, A commentary on Horace, Odes II, Oxford, Clarendon Press.

Ramírez de Verger A. y Fernández Valverde A., 1997, Marcial. Epigramas, 2 vols., Madrid, Gredos.

Soter I., 1528, Epigrammata Graeca Veterum elegantissima, [...] per Ioannem Soterem collecta, nuncque iterum/edita. Coloniae, s.e. [Biblioteca Nacional de España R. 2/70863].

Sullivan J.P., 1991, Martial: the unexpected classic. A literary and historical study, Cambridge, Cambridge University Press.

Traver Vera Á., 2014, «La importancia de las polianteas para la recepción de Lucrecio en España durante los siglos Xvi y xviı», Philologica Canariensia, 20, p. 135-152.

Usener H., 1996, Epicurea, Stuttgart, Teubner.

Vega Carpio L. de, 1761, Colección de las obras sueltas, assí en prosa, como en verso, de D. Frey Lope de Vega Carpio, del hábito de San Juan, t. III, Madrid, Don Antonio de Sancha. 